\title{
Clinical spectrum of COVID-19 and plasma angiotensin II levels
}

\author{
Ume L. Abbas ${ }^{1,2, *}$, An-Lin Cheng ${ }^{2}$, Shital M. Patel ${ }^{1}$, Sidra Younus ${ }^{3}$, Gustavo A. Rivero ${ }^{1}$, \\ Todd M. Lasco ${ }^{1}$ and Mayar Al Mohajer ${ }^{1}$ \\ ${ }^{1}$ Baylor College of Medicine, One Baylor Plaza, Houston, TX 77030; \\ ${ }^{2}$ University of Missouri-Kansas City, 2411 Holmes St, Kansas City, MO 64108; \\ ${ }^{3}$ Houston Methodist Hospital, 6565 Fannin St, Houston, TX 77030, USA.
}

\begin{abstract}
Angiotensin II levels in COVID-19 are controversial. We studied 12 hospitalized patients, including their baseline levels of peripheral lymphocyte subsets (via flow cytometry) and plasma angiotensin II (via radioimmunoassay). Controls comprised radioimmunoassay's 124 healthy subjects. Angiotensin II levels (pg/ml) were elevated among patients versus controls (Mean \pm standard deviation: $98.8 \pm 146.9$ versus $23.7 \pm 15.6, \mathrm{p}<$ 0.0001 ; Median, interquartile range: 27,20 to 116 versus 22,14 to 28 ). Half the patients had lymphocytopenia $\left(<1000\right.$ cells $\left./ \mathrm{mm}^{3}\right)$, and the CD3+/CD4+ counts were negatively associated with body mass index, viral load, hospital stay and non-home discharge. Angiotensin II imbalance appears to be a biomarker for COVID-19 morbidity and merits further investigation.
\end{abstract}

KEYWORDS: severe acute respiratory syndrome coronavirus 2 (SARS-CoV-2), coronavirus disease 2019 (COVID-19), renin-angiotensin-aldosterone system (RAAS), angiotensin-converting enzyme 2 (AngII), lymphocytopenia, biomarker.

\section{INTRODUCTION}

The role of renin-angiotensin-aldosterone system (RAAS) in the pathophysiology of coronavirus

\footnotetext{
*Corresponding author: abbasu@umkc.edu
}

disease 2019 (COVID-19), is unclear [1]. The functional receptor of severe acute respiratory syndrome coronavirus 2 (SARS-CoV-2) is angiotensin-converting enzyme 2 (ACE2), a primary enzyme within the counter-regulatory axis of the RAAS. In the classical system, renin cleaves angiotensinogen to form angiotensin I, which is converted to angiotensin II (AngII) by the angiotensin-converting enzyme (ACE). Conversely, ACE2 converts AngII, a vasoconstrictive and proinflammatory peptide, into counter-active angiotensin-(1-7). Increased activity of ACE-AngII relative to ACE2-Ang-(1-7) might drive the pulmonary and cardiovascular injury in COVID-19 [1]. However, the studies thus far have shown mixed results [2-7]. We sought to investigate further, AngII levels and their relevance in COVID-19.

\section{MATERIALS AND METHODS}

We conducted a retrospective review of patients hospitalized with COVID-19, referred to our care, from June 1 to June 14, 2020. Inclusion criteria included a positive reverse transcription polymerase chain reaction (RT-PCR) test for SARS-CoV-2 (via nasopharyngeal swab) on presentation, and admission to an intensive care or step-down unit. COVID-19 was classified, as mild, moderate, severe or critical, per the World Health Organization criteria [8]. Data were abstracted from the electronic medical records and included (Table 1) 
Ume L. Abbas et al.

\begin{tabular}{|c|c|c|c|c|c|c|c|c|c|c|c|c|}
\hline 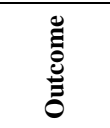 & 兽 & 总 & 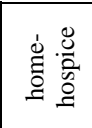 & 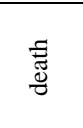 & 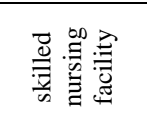 & 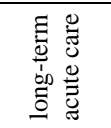 & 兽 & 言 & 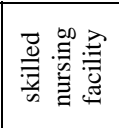 & 荤 & 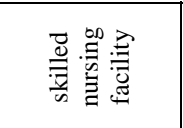 & 言 \\
\hline 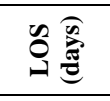 & 0 & $\infty$ & $\therefore$ & $\infty$ & $\exists$ & ח & $\nabla$ & m & $m$ & N & $\stackrel{2}{2}$ & $m$ \\
\hline 离 & 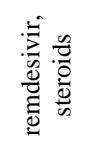 & 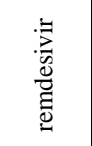 & 营 & 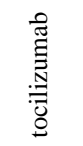 & 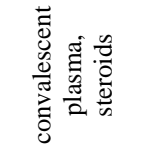 & 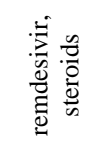 & 兽 & 蒿 & 駦 & 冚 & 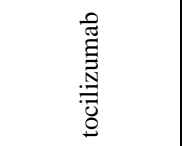 & 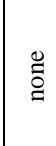 \\
\hline 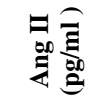 & 苚 & g & $\stackrel{\sim}{v}$ & $\vec{\sim}$ & $\stackrel{g}{ }$ & 员 & $\stackrel{\unrhd}{\stackrel{g}{9}}$ & $\cong$ & $\hat{\lambda}$ & $=$ & $\mathbb{z}$ & $\stackrel{\sim}{\sim}$ \\
\hline 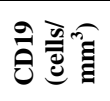 & g్ & స̃ & $\stackrel{\varrho}{\leftrightarrows}$ & $\sigma$ & $\stackrel{i}{i}$ & $\stackrel{2}{m}$ & 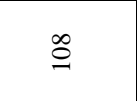 & 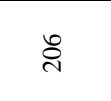 & 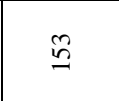 & $\stackrel{m}{=}$ & g & 学 \\
\hline 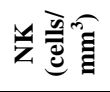 & 于 & $\nexists$ & $\stackrel{\text { ज }}{\text { I }}$ & 8 & $\stackrel{\sim}{N}$ & in & $\infty$ & $\stackrel{\cong}{\approx}$ & $\underset{\infty}{0}$ & 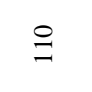 & $\overrightarrow{0}$ & $\stackrel{\infty}{\beth}$ \\
\hline 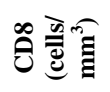 & 品 & $\tilde{\Xi}$ & $\cong$ & 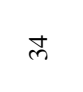 & ल्ल & 爷 & 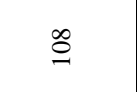 & নิ & 㚭 & స్ & 足 & d \\
\hline 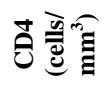 & $\stackrel{\infty}{\infty}$ & 命 & $\bar{\Xi}$ & $\stackrel{\circ}{9}$ & 苛 & $\stackrel{\sim}{\infty}$ & 另 & $\vec{\delta}$ & $\infty_{\infty}^{\infty}$ & 곰 & $\stackrel{\$}{\infty}$ & 总 \\
\hline 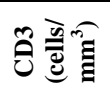 & $\stackrel{I}{\exists}$ & $\stackrel{8}{\circ}$ & \& & $\stackrel{g]}{\sigma}$ & ஜ & 品 & Sే & $\stackrel{\circ}{\not}$ & 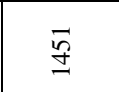 & $\stackrel{\substack{0 \\
\infty \\
\infty}}{\infty}$ & 点 & 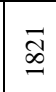 \\
\hline 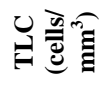 & స్ & $\stackrel{\infty}{\Rightarrow}$ & 今్ & $\stackrel{g}{g}$ & $\stackrel{\substack{\infty \\
i n}}{\infty}$ & $\tilde{\aleph ్ ~}$ & 怘 & $\stackrel{\circ}{\infty}$ & $\stackrel{\stackrel{g}{9}}{\stackrel{g}{*}}$ & $\stackrel{g}{\circ}$ & 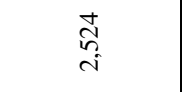 & 总 \\
\hline 与产 & $\stackrel{\infty}{\stackrel{\infty}{\sim}}$ & กิ & $\frac{\pi}{z}$ & $\stackrel{\leftrightarrow}{\mathrm{i}}$ & 啷 & $\frac{\pi}{z}$ & $\stackrel{m}{d}$ & $\overrightarrow{\dot{m}}$ & $\overrightarrow{\mathrm{d}}$ & $\stackrel{0}{\mathrm{~N}}$ & बे. & $\mathbb{z}$ \\
\hline 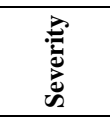 & 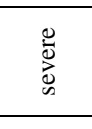 & 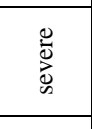 & 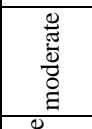 & 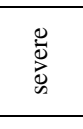 & 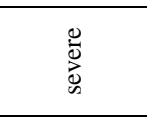 & $\overline{\widetilde{E}}$ & 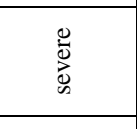 & 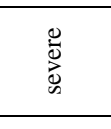 & 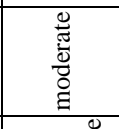 & 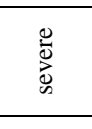 & 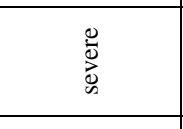 & 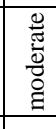 \\
\hline 㛞 & 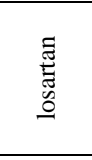 & 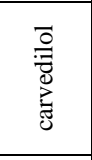 & 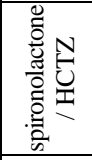 & 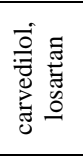 & 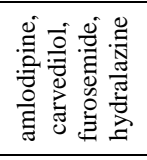 & 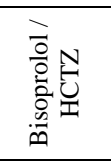 & 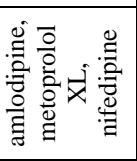 & 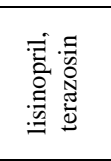 & 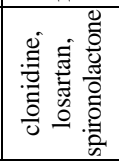 & $\overleftrightarrow{z}$ & 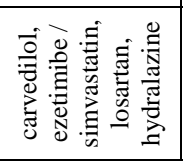 & 兽 \\
\hline 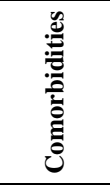 & $\begin{array}{l}\text { 忘 } \\
\text { 畜 }\end{array}$ & $\begin{array}{l}\text { 忌 } \\
\text { 去 }\end{array}$ & 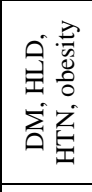 & 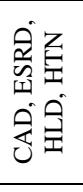 & 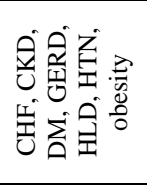 & 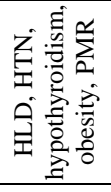 & 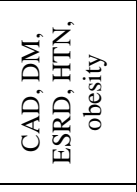 & 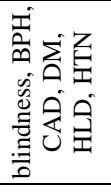 & 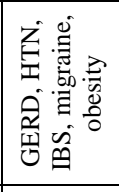 & 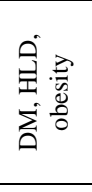 & 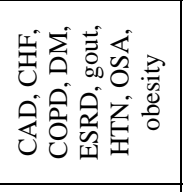 & 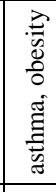 \\
\hline 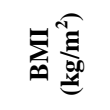 & 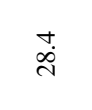 & 号 & $\begin{array}{l}0 \\
\dot{m} \\
\dot{m}\end{array}$ & $\stackrel{\infty}{\stackrel{\infty}{\sim}}$ & 孞 & $\underset{m}{m}$ & 길 & $\overrightarrow{\mathrm{d}}$ & 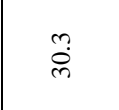 & 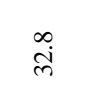 & $\begin{array}{l}\text { m. } \\
\text { D్ల }\end{array}$ & 8 \\
\hline 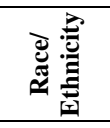 & 爱表 & 尊零 & 尊重 & 善重 & 善重 & 爱央 & 善金 & 曾 & 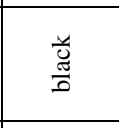 & 前无 & 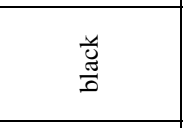 & 鄫 \\
\hline 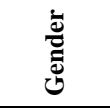 & 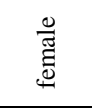 & 造 & 荡 & $\stackrel{\stackrel{\Xi}{\Xi}}{\Xi}$ & 氶 & 造 & 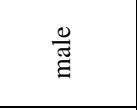 & 营 & 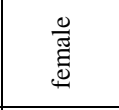 & 总 & $\stackrel{\square}{\Xi}$ & 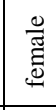 \\
\hline 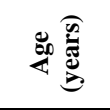 & f & $\stackrel{+}{N}$ & 吕 & $\vec{\infty}$ & $\infty$ & f & 吕 & $\cong$ & $\infty$ & $\stackrel{m}{m}$ & 8 & $\vec{m}$ \\
\hline$\AA$ & - & N & $m$ & + & n & 0 & $\wedge$ & $\infty$ & $\sigma$ & 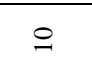 & $\exists$ & $\approx$ \\
\hline
\end{tabular}


comorbid conditions, outpatient medications, laboratory data and length of stay (LOS). The laboratory data, based on the prevailing protocols and/or clinicians' discretion, encompassed various biomarkers, obtained at baseline ( $\sim$ admission) and during follow-up. We focused on the baseline levels of peripheral lymphocyte subsets (measured via flow cytometry) and plasma AngII (measured via radioimmunoassay [RIA]; Quest Diagnostics). Controls comprised 124 subjects (healthy, normotensive, 61 females and 63 males, aged 1865 years) of Quest's RIA (limit of quantification [LOQ]: $12-500 \mathrm{pg} / \mathrm{ml}$; normal values: $\leq 52$ $\mathrm{pg} / \mathrm{ml}$ ). Outcomes included hospital-death and discharge to home, skilled nursing facility or long-term acute care, and excluded re-admission and post-acute sequelae of COVID-19.

Data were analyzed using SPSS (version 25), applying Mann-Whitney U, Chi-square and Spearman's correlation tests, as appropriate. Student's t-test and box-plots were employed to compare the mean and median AngII values among patients and controls, respectively.

Approval for this study was obtained from the Baylor College of Medicine's institutional review board.

\section{RESULTS}

Twelve patients were included in our analyses (Table 1). Two patients (both female, aged 20 and 41 years, discharged to home after a 3- and 2-day stay, respectively) were excluded due to lack of laboratory data. The median age was 72 years (interquartile range [IQR]: 47-84 years). Women comprised $67 \%$ and most patients had severe or critical disease (75\%). COVID-19-specific therapies included steroids (25\%), remdesivir (25\%), tocilizumab $(25 \%)$ and convalescent plasma (8.33\%). The median LOS was 7 days (IQR: $3-11$ days). Seven patients $(58.3 \%)$ discharged home, while four had non-home discharge. One patient $\operatorname{died}(8.3 \%)$.

Six patients had lymphocytopenia $(<1000$ cells $/ \mathrm{ml}$ ), with decreased $\mathrm{CD} 3+\mathrm{CD} 4+$ and/or CD8+ T cell counts. Contrastingly, AngII levels were elevated $(>52 \mathrm{pg} / \mathrm{ml})$ in four patients. The highest level $(>500 \mathrm{pg} / \mathrm{ml})$ was in a patient requiring prolonged intensive care unit stay (53 days) with acute respiratory distress syndrome and severe hypertension. AngII was normal (21 $\mathrm{pg} / \mathrm{ml}$ ) in the patient who died, albeit with severe lymphocytopenia. The AngII levels among patients were higher compared to controls (Figure 1).
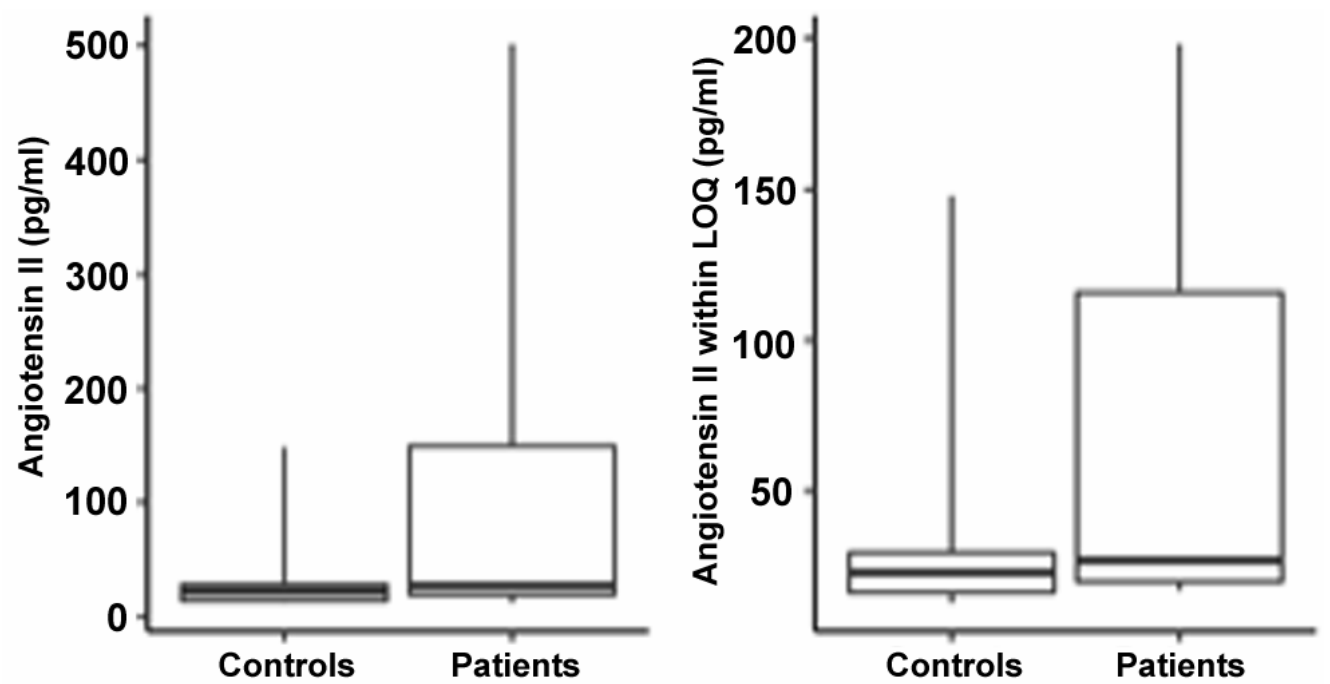

Figure 1. Plasma angiotensin II levels among healthy controls and COVID-19 patients.

Boxplots showing the median, interquartile range, minimum and maximum values of angiotensin II $(\mathrm{pg} / \mathrm{ml})$ among controls and patients. Left panel: using all data values $(\mathrm{n}=124$ versus $\mathrm{n}=11)$. Right panel: using data values within the limit of quantification $(n=103$ versus $n=9)$. 
Mean [standard deviation (SD)] plasma AngII values for patients versus controls were 98.8 [146.9] versus 23.7 [15.6] $\mathrm{pg} / \mathrm{ml}, \mathrm{p}<0.0001$; and median [IQR] AngII values were 27 [20-116] versus 22 [14-28] $\mathrm{pg} / \mathrm{ml}$. Excluding the two patients and 21 controls with levels above or below LOQ, mean [SD] AngII values were 63.8 [66.5] versus 26.1 [16.1] pg/ml, $\mathrm{p}<0.0001$; and median [IQR] AngII values were 27 [21-83] versus 23 [16.5-29.5] pg/ml.

The patients' AngII levels were not correlated with other variables (shown in Table 1) nor associated with hospitalization outcomes. CD3+ cell counts were higher for $\operatorname{LOS} \leq 7$ versus $>7$ days (median 988 versus 530 cells $/ \mathrm{mm}^{3} ; \mathrm{p}=$ 0.05), while CD4+ percentages were higher for home versus non-home discharge (median 47\% versus $34 \% ; \mathrm{p}=0.015)$. RT-PCR cycle threshold values ( inversely correlated with viral load) were positively correlated with CD4+ cell counts $(\mathrm{r}=0.609 ; \mathrm{p}=0.047)$, while body mass indices (BMIs) were negatively correlated with $\mathrm{CD} 4+$ percentages $(r=-0.635 ; \mathrm{p}=0.026)$.

\section{DISCUSSION}

We examined the characteristics, inpatient data, outcomes, select immune markers and AngII levels, in a cohort of hospitalized patients with moderate to critical COVID-19. The baseline AngII levels among patients were elevated, while the $\mathrm{CD} 3+/ \mathrm{CD} 4+\mathrm{T}$ cell counts were depressed and negatively associated with BMI, viral load, hospital stay and non-home discharge.

Similar to our study, lymphocytopenia, especially reduced $\mathrm{CD} 4+$ and $\mathrm{CD} 8+$ cell counts at hospital admission, have been found to predict COVID-19 disease progression [9]. Conversely, the studies to date have substantial qualitative and quantitative differences, in terms of the measured AngII levels among COVID-19 patients and controls [2-7].

Our findings are in agreement with two previous studies [2, 3]. Plasma AngII levels were elevated among 12 patients with COVID-19 (half having acute respiratory distress syndrome and lymphocytopenia) compared to eight healthy controls, and positively correlated (unconfirmed by us) with viral load and lung injury [2]. Of note, the AngII levels in this study $(\sim$ median $300 \mathrm{pg} / \mathrm{ml}$ among patients versus $100 \mathrm{pg} / \mathrm{ml}$ among controls), were considerably higher than ours (median 27 versus $22 \mathrm{pg} / \mathrm{ml}$ ). Similarly, in a larger study of 82 non-hypertensive patients with mild, moderate and critical COVID-19 and 12 critically ill controls, the COVID-19 patients had elevated plasma AngII levels, that correlated with disease severity, and exceeded versus the controls [3]. The mean [SD] AngII levels (pg/ml) were 148 [25.5] for mild, and 190.3 [93.3] and 212.7 [85.7] for moderate and severe COVID-19, versus 135.1 [32.8] for critical controls. In contrast, our findings are in disagreement with some other studies that found similar [4, 5] or lower [6, 7] AngII levels, among patients compared to controls. Different methodologies and COVID-19-phenotypes [10] may explain this variance, including the use of enzyme-linked immunosorbent assay in the previous studies (except for liquid chromatography-mass spectrometry in [7]), which has low specificity and yields variable AngII concentrations, as opposed to RIA, employed by us [11]. In a prospective study of 22 patients with moderate or severe COVID-19 and 11 matched moderately ill controls, the median [IQR] AngII was 15.3 [8.031.1] $\mathrm{pM}(\sim \mathrm{pg} / \mathrm{ml})$, for subjects overall, using RIA [12]. Interestingly, there was a trend towards higher mean AngII levels (pM) ranging from moderately ill controls $(\sim 16.5)$, to moderately $(\sim 18.3)$ and severely $(\sim 24.4)$ ill COVID-19 patients, though these differences were not statistically significant in this pilot study [12].

\section{CONCLUSION}

This study found elevated AngII levels among hospitalized patients with COVID-19 compared to controls. Rigorous evaluation of the RAAS, using standardized methods and clinical trials, and including various components and pathways, could provide clarification on whether or not RAAS imbalance is a driver of the severity of COVID-19, and may yield clinically useful biomarkers and therapies [1].

Limitations of this study include its small sample size, retrospective design, external controls and limited RAAS evaluation. Whether high AngII levels in patients hospitalized with COVID-19 are from pre-existing health-conditions and/or SARS$\mathrm{CoV}-2$ is unclear. Nevertheless, AngII imbalance 
seems to be a biomarker for morbidity in COVID19. Further research into mutual effects of SARSCoV-2 and RAAS is warranted.

\section{SOURCE OF FUNDING}

None.

\section{CONFLICT OF INTEREST STATEMENT}

MA receives honoraria from the University of Arizona Continuing Medical Education Office and Society for Healthcare Epidemiology of America, and is a committee/board member at latter, Infectious Disease Society of America and Certification Board of Infection Control and Epidemiology, Inc. SMP is a recipient of AIDS Education Training Center grant from the Health Resources and Services Administration. GAR receives consulting fees from the Karyopharm Therapeutics and Bristol Myers Squib. None for the remaining authors.

\section{ABBREVIATIONS}

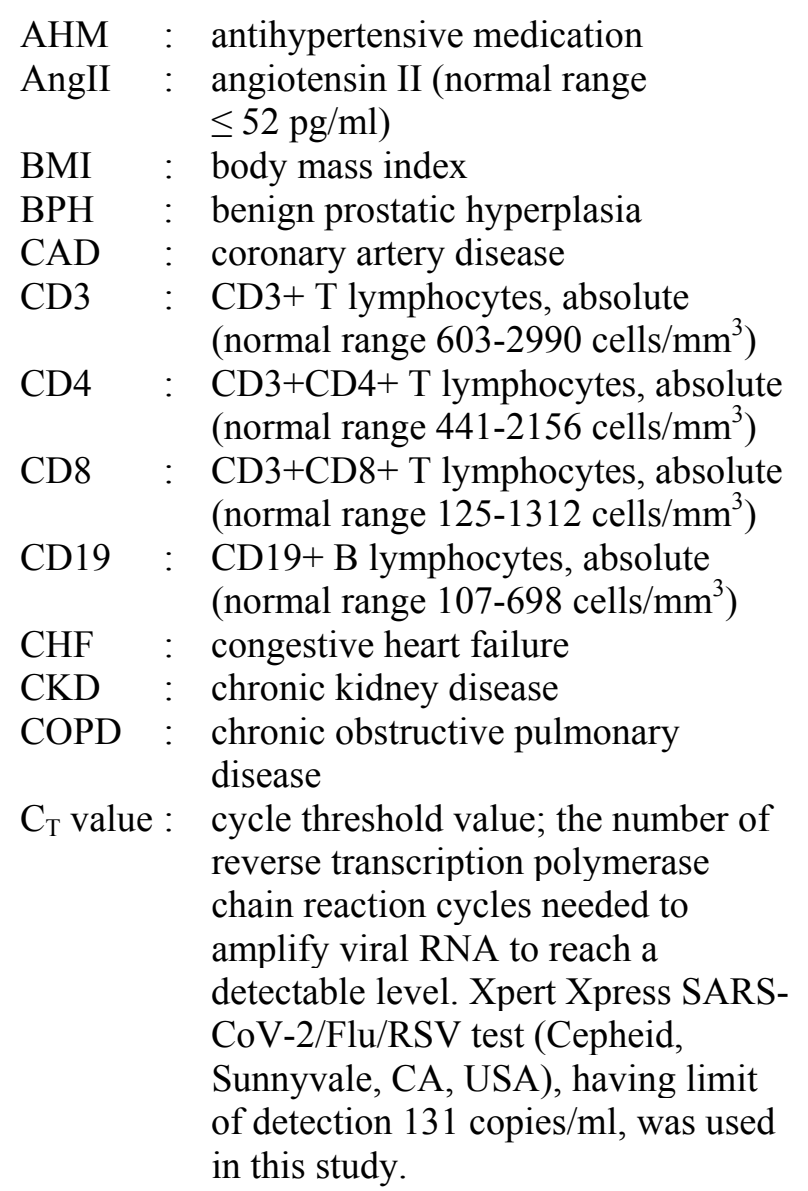

$\begin{array}{lll}\text { DM } & : & \text { diabetes mellitus } \\ \text { ESRD } & : & \text { end stage renal disease } \\ \text { GERD } & : & \text { gastroesophageal reflux disease } \\ \text { H } & : & \text { Hispanic } \\ \text { HCTZ } & : & \text { hydrochlorothiazide } \\ \text { HLD } & : & \text { Hyperlipidemia } \\ \text { HTN } & : & \text { hypertension } \\ \text { IBS } & : & \text { inflammatory bowel syndrome } \\ \text { LOS } & : & \text { length of stay } \\ \text { NA } & : & \text { not available } \\ \text { NK } & : & \text { CD16+ CD56+ natural killer cells, } \\ & & \text { absolute (normal range } 95-640 \\ & & \text { cells/mm }{ }^{3} \text { ) } \\ \text { NH } & : & \text { Non-Hispanic } \\ \text { OSA } & : & \text { obstructive sleep apnea } \\ \text { PMR } & : & \text { polymyalgia rheumatica } \\ \text { TLC } & : & \text { total lymphocyte count, absolute } \\ & & {\text { (normal range } 1.32-3.57 \times 10^{3}}^{3} \\ & & \text { cells/mm }{ }^{3} \text { ) } \\ \text { XL } & : & \text { extended release }\end{array}$

\section{REFERENCES}

1. Sparks, M. A., South, A. M., Badley, A. D., Baker-Smith, C. M., Batlle, D., Bozkurt, B., Cattaneo, R., Crowley, S. D., Dell'Italia, L. J., Ford, A. L., Griendling, K., Gurley, S. B., Kasner, S. E., Murray, J. A., Nath, K. A., Pfeffer, M. A., Rangaswami, J., Taylor, W. R. and Garovic, V. D. 2020, Hypertension, 76, 1350-1367.

2. Liu, Y., Yang, Y., Zhang, C., Huang, F., Wang, F., Yuan, J., Wang, Z., Li, J., Li., J, Feng, C., Zhang, Z., Wang, L., Peng, L., Chen, L., Qin, Y., Zhao, D., Tan, S., Yin, L., $\mathrm{Xu}$, J., Zhou, C., Jiang, C. and Liu, L. 2020, Sci. China Life Sci., 63, 364-374.

3. Wu, Z., Hu, R., Zhang, C., Ren, W., Yu, A. and Zhou, X. 2020, Crit. Care, 24, 290.

4. Henry, B. M., Benoit, S., Lippi, G. and Benoit, J. 2020, Prog. Cardiovasc. Dis., 63, 702-703.

5. Rieder, M., Wirth, L., Pollmeier, L., Jeserich, M., Goller, I., Baldus, N., Schmid, B., Busch, H. J., Hofmann, M., Kern, W., Bode, C., Duerschmied, D. and Lother, A. 2021, Am. J. Hypertens., 34(3), 278-281.

6. Ozkan, S., Cakmak, F., Konukoglu, D., Biberoglu, S., Ipekci, A., Akdeniz, Y. S., Bolayirli, I. M., Balkan, I. I., Dumanli, G. Y. 
and Ikizceli, I. 2021, Crit. Care Med., 49(6), e613-e623.

7. Valle Martins, A. L., da Silva, F. A., BolaisRamos, L., de Oliveira, G. C., Ribeiro, R. C., Pereira, D. A. A., Annoni, F., Diniz, M. M. L., Silva, T. G. F., Zivianni, B., Cardoso, A. C., Martins, J. C., Motta-Santos, D., Campagnole-Santos, M. J., Taccone, F. S., Verano-Braga, T. and Santos, R. A. S. 2021, ERJ Open Res., 7(3), 00114-2021.

8. COVID-19 Clinical Managment: Living guidance 25 January 2021. Available at: https://www.who.int/publications/i/item/ WHO-2019-nCoV-clinical-2021-1

9. Zhang, X., Tan, Y., Ling, Y., Lu, G., Liu, F., Yi, Z., Jia, X., Wu, M., Shi, B., Xu, S.,
Chen, J., Wang, W., Chen, B., Jiang, L., Yu, S., Lu, J., Wang, J., Xu, M., Yuan, Z., Zhang, Q., Zhang, X., Zhao, G., Wang, S., Chen, S. and Lu, H. 2020, Nature, 583(7816), 437-440.

10. DeMerle, K., Angus, D. C. and Seymour, C. W. 2021, JAMA, 325, 20412042.

11. Chappell, M. C., Pirro, N. T., South, A. M. and Gwathmey, T. M. 2021, Hypertension, 77, e29-e31.

12. Files, D. C., Gibbs, K. W., Schaich, C. L., Collins, S. P., Gwathmey, T. M., Casey, J. D., Self, W. H. and Chappell, M. C. 2021, Am. J. Physiol. Lung Cell Mol. Physiol., 321, L213-1218. 